\title{
A re-examination of the typology of peraluminous granite types in intracontinental orogenic belts
}

\author{
Carlos Villaseca, Luis Barbero and Victor Herreros
}

\begin{abstract}
A BSTRACT: Conventional rock classification diagrass do not distinguish the variery of perajuminous rock series. Moreover. peraluminour granite iypes bave nol been clearly discriminaled in recene revisions. The sludy of several peraluminous series in differene ineracodinental orogenic beits reveals that four distinct grouds can be defined. Using an A-B diagram, vhese lour groups arc: (1) highly peraluminous graniloids ( $h P$ ) characcerised by high A values and yppified by an increase in peraluminosicy coward the most mafic variecies; (2) modoracely peraluminous grasitoids (mP) whicb oocupy the intermediate field and gederally sbow increasing peralusoinosity lowards the most felsic varieties: (3) low peraluminous granitoids (IP) which plot in the lowest parn of (be pera)uminous Geld defining negative slope (rends: (4) bigbly fclsic peraluminous grasiles $(S P)$ with paorly defined variation trends.

In intracontinental orogenic belts, lbe gensis of peraluminous granitic serics is favoured by the abuadance of lerile crustal protoliths, mainly mclapelites. mctaigneous rocks and mctagrcywackes. The diffeulty of altaining teroperatures in excess of $950^{\circ} \mathrm{C}$ al lower crustal levels during the coelonothermal evolution of thickened crust. inhibits the parial meling of more basic sourocs. Although the physieal perameters of the melting process influena their chemical and mineralogical characicristies source rock composition ulturately deternincs the degree of peraluminosity of the granuic serics
\end{abstract}

KEY IVORDS: collisional orogenic magmatism crustal protoliths, granite classificalion.

Convencional rock classificalion diagrams (c.g. TAS and $\mathrm{K}_{2} \mathrm{O}-\mathrm{SiO}_{2}$ plots) do not discinguish the variety of peraluminous rock scries and recourse is frequently made to the peraluminosity index of Shand (1927). Also, rooene alphabetic classificacioos of graniroids (MISA classificaion) which jre more genclically biased do nol overcome the simple dichoromy oclwcen peraluminous and mecaluminous series. Rocks in which the molecular proportion of $\mathrm{Al}_{2} \mathrm{O}$, is higher than $\mathrm{CoO}+\mathrm{Na}_{2} \mathrm{O}+\mathrm{K}_{2} \mathrm{O}$ arc icrmod peraluminous (Shand 1927). Usually. bue nol nocararily. Ihey have nomalive corundum and such characteristic modal phaes as biolitc, musoovice, gameh cordierice and aluminium silicares. Most relsic ignoous rocks 3re peraluminous (Dcbon \& Le For (983), bur generally the $\mathrm{Al}, \mathrm{O}$, exoess is due 10 biolite alone (Miller 1985). Iencous rocks containing alunsinium pha.es olhce thao bioticc. though common and widespread. ore subordinale. The difference in degree of peraluminosily in felsic igaeous rocks has been discusect by several authors (Debon \& Le Fon 1983; Miller 1985) in order 10 esisblish differenl peraluminous series and. more importanily. since the publication of the 1- and $S$-cype classifization scheme of Choppell \& While $\{1974\}$, to discuss pecrogenclic problems releled to the origin and significanoc of those igneous rocks with strongly peraluminous composicions.

Deboo \& Lc Fon (1983) used a binary diagram with - Deraluminosily parameicr $A=A \mid-(K+N a+2 C a)$ and a differentiation index $B=F C+M_{B}+T_{i}$ and suggested crilcria for achieving a rigorous chemical-mineralogical definition of sluminous associalions, bul wishoul slating how many lyocs of peraluoninous series can be lound.

Miller (1985) provosed a elassification of peraluminous graniles using the AFM diagram in wbich he escablished livo main fields sirongly peraluminous (Ps) and wexkly peraluminous ( $P$ ii) serics. each with different onineralogical characicr. istic This kind of classification diagram bas the problem that several igneous series cross bolh the Ps and $\mathrm{Pw}$ fields as the differentiation index increases.

Recencly Barbarin (1996) made a revision of the genesis of peraluminous graniles in which the staring point was the consideration the the most significant volumes an made up of only two type produced by extensive anatexis of crustal rocks. However. we show below thac from detailed study of several orogenic segmenis il is possible 10 recognise al leasl lour types of peraluminous granitoids. We also altempl to shorv that the complex diversily of felsic magmatism may be best clacified by the use of an A-B diagram.

\section{Variety of peraluminous series}

In order 10 establish the divessity of ensially derived peraluminous scrics granicic samples from several arcas have been selocted and plocced on an A-B (Deton \& Le Fort 1983) diagram (Fig 1). Firsh peraluminous granitoids from the Spanish Ceneral Region have been plotled. as they have been thoroughly studied from a mineralogical, isotopic and geochemical point of vicw (Villaseca \& Barbero 1994; Villaceos et ol. 1998) and also becausc is is possible 10 distinguish the four ypos of peraluminous granices that can be found in an orogenic segment (Fig la). On Figure ib, several series from the Lachlan Fold Belt in Australia are assembled. and on Figure lc other granitic series from difierent orogenic segmedts are plotted for comparison.

It is noticeable that, despite the fact that the four types of granitic series defincd in the Spanish Central Region can be found in other orogenic seciura, gratsite rescareliens have focused their attencion on the simple peraluminous versus metalumioous dichotomy (associated with the I- and S-lype petrogenecic discussion), or have distinguished only livo iypo 


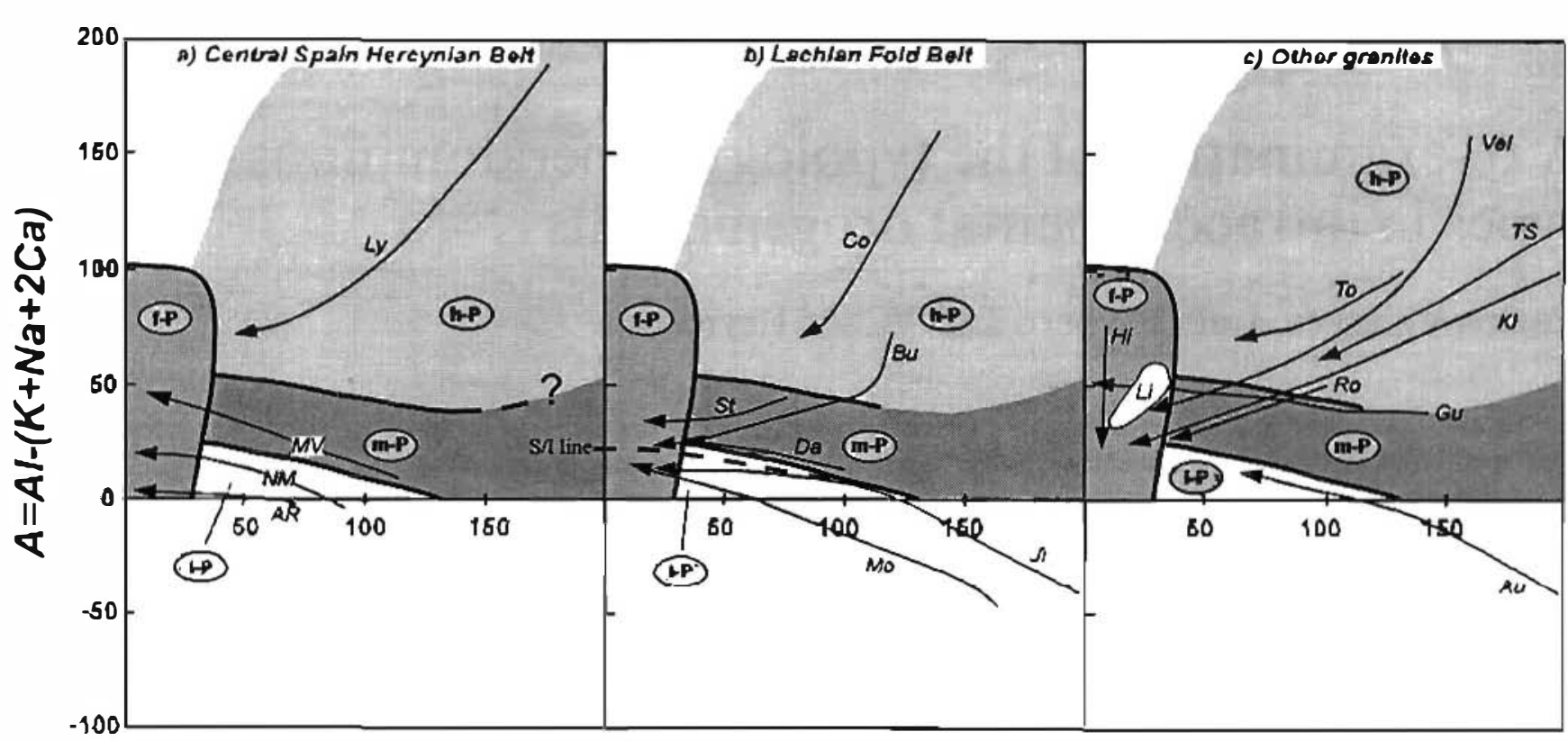

\section{$B=F e+M g+T i$}

Figure I A-B diagram (modifiod feon Deboo \& Le Forl 1983) for diffesenl granilic series: (a) Ceniral Spain Hereymian Belt: Ly (Layos geanice. Barbern \& Villasera 19921, MV. NM und AR (Mora-Vensas. Las Novas del Miarques and La Alalaya Real plulons Villaerea el al. 1998). (b) Laclilan Fold Bell series: Co. Si and Mo (Cooms. Strahbogic and Moruya serice, Cobapell el of. 1991), Bu and Ji (Bullenballong and Jindabyne. Hinc ef of. (978) and Da (Dalgety suile. Wbile el al. 197: Chippell el al. 1991). (c) Oither graniles: To (Tourcol. Horiz \& Barbay 1991), Ki (Kinsman suilc, Clark \& Lions 1986), Ro (Royerch Si(rssi \& Cuncy 1993). Gu (Gueret. Debon \& Le Fort 1983). Au (Moldanubion IB 1-1ype sulle. Lielw es ul. 1989). Li (Limousin, Leger cl al. 1990). Hi (Himalayan leucogranilsi, Debon \& Le Fon 19831. Ts (Trois Scigncurs, Wickhan 1987). and Vel (Velay, Wisliamson es al. 1997). Fields are: is $P$ (highly peraluminous), inP (moderately peraluerinousl. IP (Jow Dersluminous). SP (felsic ocroluminous). Dolled line on figure IB is i he I/S boundary line.

of peraluminuus graniles: peraluminous gronodiorises and analcclic leucogranites (Lameyre 1988). Barbarin (1996) has named these livo lypes CPGs (pemluminous cordicritc-bcaring conalites 10 monzogratiles) and MPGs (pcraluminous lwo mico monzogranices and leucogranics), respeciivcly.

\section{I.1. Highly peraluminous granitoids (hP)}

In this field. granitic series with a high degree of peraluminosily plot as defining $x$ typical positive trend. i.e. increasing peraluninosity lowards the most roafic varieties. This corresponds 10 the iypical S-lype irend (White \& Chappell 1988). Nevertheless, only a rew S-lype suitcs or supersuitcs from the Lachlan Fold Belt clearly plor in this ficld. paricularly the Cooma and Bullenbalong suices from the Kosciusko bollholith (Hine el al. 1978: Cbappcll el al. 1991) (Fig. Ib). In olher orogenic scciors. although more scarce, such graniles are nol absent. Thus. in the Spanish Central Region. the Layos restic rich granioids plot in this $h P$ field (Barbero \& Villaseca 1992 j. In olher Hercymian seclors, the Trois Seigneurs gradics in the Pyrences (Wickham 1987), ihe Tourem cordieritebearing granites in northern Portugal (Holy. 1989), the Velay anatectic granites (Williamson $c l d .1997$ ) and the mosi mafe facies of the Royere granite (S(ussi \& Cuncy 1993), bolth in the French Massif Central. are examples of this hP lype (Fig (c). Far irom the Hercyaian orogen. The Kinsman imerusive suite of the eastem USA (Clark \& Lyons 1986) also belongs 10 this group (Fig. IC).

All these granilic suites are characterised by the presence of aluminous mineral phases orther than biotite. which in several cases can be the most abundani mafic phace. Cordierise or gamet (almandine-pyrope series) are the most typical aluminous phases but it is nol unusual 10 find acoessory sillimanite. In general, two mica granites sensu siricio are searce as most of the AP granices are characieriscic of bigb-T eatazonal arcis, equivalcne 10 regional migmatice ecrains or regional aurcole granices (Whitc \& Chappcl 1988). Cordicritc from this cype of hP granite is lexturally and chemically different from that of olber peralumioous granizes. reflecling its periteclic origin in contrast with the late magmatic origin of cordicritc in higher Icvel pcraluminous granites (Williamson el el. 1997). Anolher remarkable cliaracteristic of the hP type. especially seen in the most peraluminous suites from caltazonal a reas (Layos, Coomn, Tourem, Trois Seigneurs, Velay), is its greal heterogencity and the abundance of restitic enclaves.

\section{Moderately peraluminous granitoids (mP)}

Thexe granitex occupy an intermediatc ficld in the A.B diagram generally showing negative slope trends, i.c. increasing peraluminosity lowards the more differentialed samples. Most of the Australian moderately peraluminous $S$-types plot in this ficld (c.g. Daigety suicc, White et al. 1977). The Strathbogic suite from Central Vicloria ylso plots in this field but with a positive slope, withoue reaching such high $A$ values as those or the hP cype (Fig. Ib). Hercynian cordierice-bearing roonzogranitcs (Hercyniad S-lype ufter Pilcher 1983), such as the Margueride and Gudrel plutons in the French Massir Central (Debon \& Le Forl 1983 ) or Mora-Venlas and Hoyo de Pinares plurons in the Spanish Central Region, are representative granicoids of this moderately peraluminous type (Fig. Ia and $c)$. This is the feld of peraluminous granodiontes (Lameyre 1988), also called CPG lypes (Burbarin 1990)

Most of the granites which plot in this fjedd are biotile. bearing variezies. generally with anolher mineral phase more aluminous than biotite as an acoessory phase Cordierite is the most common accessory mineral, whilst in highly fraction. ated lypes, muscovile may be dominant logelher with garnes 
of the almandine-spessarline series or olher low-lemperalure AFM minerals such as andilusic or lourmaline. Microgranular enclaves are conspicuous in thesc graniles, usually being las than $1 \%$ of the ared of oulcrop.

\subsection{Low pcraluminous gravitoids (IP)}

The lowesl parl of the peraluminous ficld is occupied by the low peraluminosity series and by the mosi cvolved renos of those series whicb evolve from metaluminous 10 slighily peraluminous compositions in cither case defining negalive slope (rends in the $A-B$ diagram (Fig 1). T'clsic l-1ypes from the Lachlan Fold Belt such as the Moruys and Jindabyne supersuites (Hine el al. 1978; Chappell el el 1991). logelher with several difierentialed calc-alkaline suites ffor example the Querigul in France and Mont Givens in Calıfornia, as relerred 10 by Debon \& Le For( 1983). plor witbin this IP ficld. In the Heccynian area from Central Spain, scveral plutons with characceristic accessory amphibole ano altanite in the less cuolved granodiorice facies plot in this narrow field of low peraluminous graniccs (sce for example La Alalaya Real. La Cabrera and Las Navas del Marqués plucons, Fig. (a). Some iransitional l-lyges of the Moldunubian Bacholith

(Licw el al. 1989) and some Caledonian 1-types (Pitcher 198j) are among granics that ploc in this IP field. It is nociccable Ihal the roore cvolved facies of this type of series can be markedly more peraluminous than the rest of the series and thus they sometimes bear aluminium-rich minerals (see. for cxample ihe gamel peraluminous $1-$ yypes and garnet-andalusitc l-types from the Namungo felsic pluton. Chappell el al. 1991, or the garnet-cordiesile leucoesalic lacics of La Cabrem l-lype pluton. Villaseca \& Barbero (994)

Mincral chemistry of AFM phases common to the inP and IP graniles is a pawcriul 100 for dislinguishing both syper af granites espocially

as cordicrite, garnet or aluminium silicate io the $M P$ sypes, or amphibole (or allanite) in the IP lypes are nol present in a paricular variely. Biotics of IP type have characieristically lower peraliuninosity with respect 10 those of the $M P$ lypes. the latrer plotting within the alumino-potassic ficld in the $\mathrm{Mg}$ versus tolal Al diagram (fig. 2 (rom Nactil el al. 1985).

When cordierile appears in both $\mathrm{mP}$ and $(P$ iypes, it usually has lextures and compositions which indicate a magmatic origin, and which are quite diflerent from those of the hP cypes. Those cordierites from /P differenliated lypos (La Cabrera piucon in the Spanish Central Region) have lower $\mathrm{Al}_{2} \mathrm{O}_{3}$ and alkali concencs, especially $\mathrm{Na}$, than cordierites from the mP lypes with similar $X_{F e}$ composition (Villaseca \& Barbero 1994). As in the $m P$ types, mafic microgranular enclaves are ividespread.

\subsection{Highly fclsic peraluminous granicoíds $(\boldsymbol{P})$}

In this region of the A-B diagram, all the above-described peraluminous series converge. Several granitic and volcanic series (sce, for cxaniple. the Macusani rhyolites Picbavant el al. 1988) are exclusively composed of very acidic members and ihus projecl within the $P P$ cype field, generaliy nol showing a Iypical varialion trend. Ncverheless, some tend to show verrical lrends and corrcspond 10 the craditionally cermed analecric leuoograniles (Lameyre 1988) or MPG cypes (Barbarin 3996). The mosi represenlalive of inis $\int 8$ type are the Himalayan-type leucograniles (Le Forl el al. 1987), and also the Limousin leucogsanites in the European Hercynides of France (Leger el of. 1990) and some of tbe Cervalos onatceuc leucogranilos in the Spanish Central Region (Darbero \& Villasica 1992).

Bolb the paucicy of mafic minerals in these highly felsic types and their emplacement level influence the petrographic characteristics of these rocks. Thus, the paraulochihonous leucograniles. poorly segrcgatcd from tbeir source region. can present a high-lcmperalurc mincral parageoesis with eypical Mg-cordierile, almaodine-pyropo garnce or sillimanice. This kind of high-icmperalure mineral paragenesis is found in most of the hP lypes from analectic areas. On lbe other band. in tbe more allochthonous epizonal leucogranices (Himalaya or Limousin), the AFM mineral parageneses are of lower temperature and pressure, and minerals tend to show aplopegsoaritic iexlures and also higher volatile concents, lypically being represented by 1 wo mica and coumaline-bearing granitoids.

\section{Discussion}

\subsection{Relorionship with ofhcr classificstion scbcmes}

On Figure 16 an $1 / 5$ boundary line has been drawn usiog ibe dala of 1 . and S-1ypa from the Lachlan Fold Bell where ibjs nomenclalure uriginatcd. II can be observed that this 1/S line coincides with the boundary line between $m P$ and IP cypes proposed in this work. Both lines show a negalive slope in the diagram and do not coincide with the peraluminous-metaluminous division. There is not an absolvte limil in peraluminosity dividiog tbe felds of $m P$ and $I P$ lypes and the boundary is a function of the degree of differentiation of the granice. as slaied by Chappell \& While (1992). The good discrimination of this mP-IP line belween acocssory cordicrice-bearing and amphibole-bcaring granites reinlorces lbis division.

The petrogenerie connotation of the I-S terminology has made ils adoplion in oller orogenic bels debacable. Furthermore. alchough there is. as noled above. a scrons similarily between the compositions of the Lachlan Fold Bclt and the Europenn Hercynian Bell ganicic series. the volumes of the several granilic series found in each orogen are differene (Fig. 2). In itse Lachlan Fold Bell, the hP cypes conscirule around onc-rhird of the cxposed granices (the Bullenballong suice alont has $11,200 \mathrm{~km}^{2}$. Chappell el ol 1991) and were eroploced al epizooal levels (somelimes even with associated volcanic rocks) in conirast 10 the less (han $5 \%$ of $h P$ (ypes in the Europcan Hercynides, where they are iypically calazonal plucons rclaced 10 migmarilic areas. In further conirast, in toe European Hercynian Belt, the most abundanl lypes fall in the $M P$ and IP fields, some of tbem close 10 the boundary belween the I-types and S-lyper from the Lachlan Fold Belt. This has led 10 the classification of some European Hercynian granites as a Iransilional senas (Liew el ol. 1989).

Aparl rom iniracontinental orogenic zones. where peralumioous gronites are really dominant, granitic basholiths also appear above subduclion zones al conlinental margins. Neverthcless, in subduction sellings peraluminous series are very scarce although some peraluminous granites can be gederated as a result of differentiation from calc-alkaline series composed olainly of gabbros 10 granodiorites. The projection of the continental margin calo-alkaline batholiths in the A-B diagram would show that the majority of the data plot in the onetalumsnous field, with the most acid varieties plotting in the IP field (soc examples in Debon \& Le Fort 1983). This is a consequence of the higher abundance of incermediate rocks in the conlidental piate nargin orogens (Fig 2). Contrasts in the abundance of petrograpbic cypes between different orogenic batholiths have led to the difficulty of reconeiling the different nomencialures. Several allemples to roconcite these different nomenclacures bave been made, as for example the distinetion of Pircber (1983) beiween Cordilleran [-types, equivalent to ibc calc-alkaline sutes from concinenıal margins, and 


\section{ACTNE CONTINENTAL MAROINS}

\section{,}

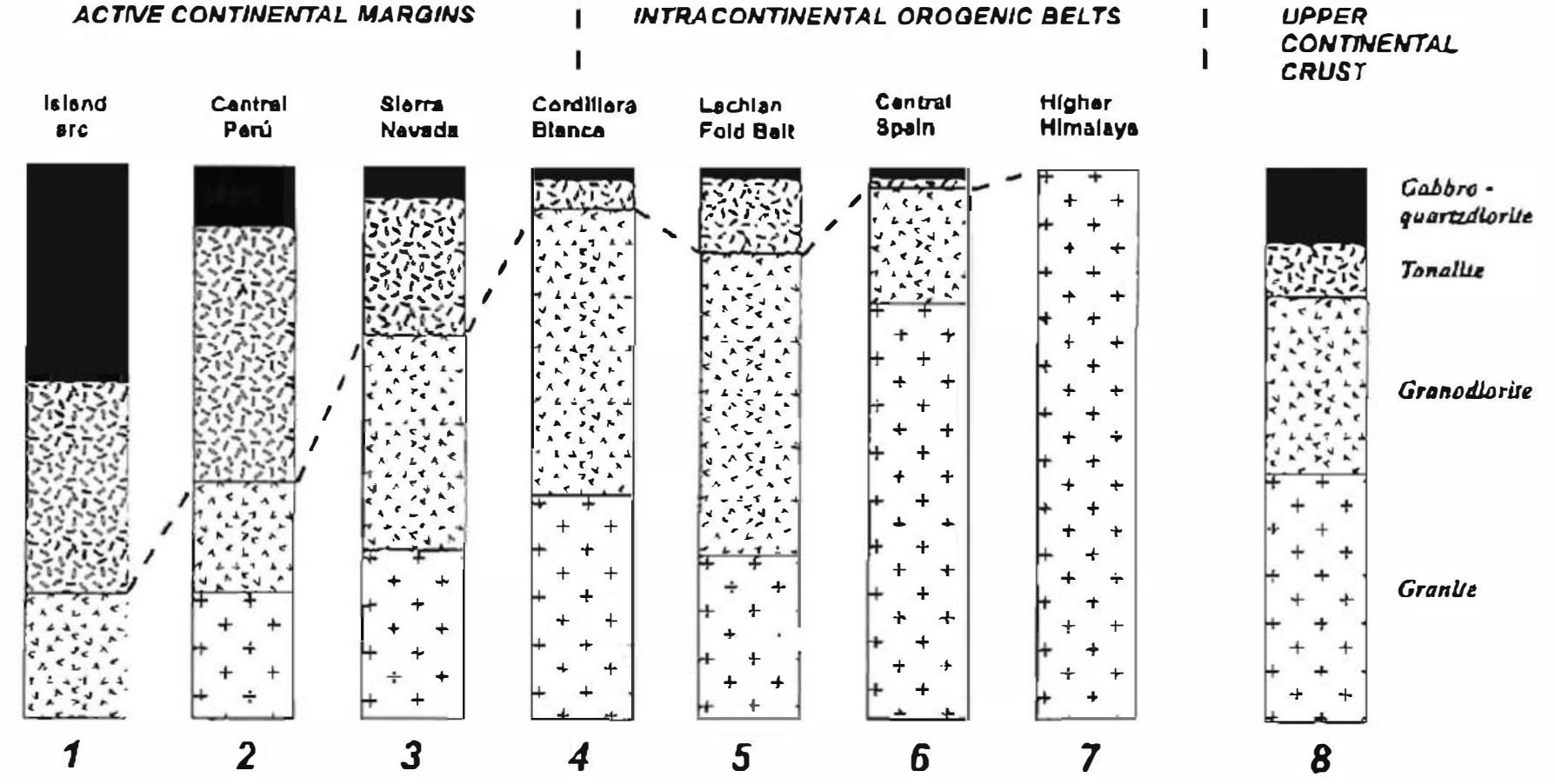

Figure 2 Cumparison of relative volumes of gabbro-quanzdiorica, lonalices, granodiorices and granjiles belween aclive continenial margins ond intracontinental oregenje batholiths. Estimaces are based on geological maps and pelrograpbic descriplion of the batboliths (1, 3. 4, 5). Other relstive volumcs are delailed by the authors 12 6. 7. 8). I= New Britain Island ane (Whalen 1985). 2= Pcruvian Coastal Batholish (Pilcher pl al. 1985). $\mathrm{J}=$ Sierra Nevada Bolholith (Baccmen el al. 196j). 4 - Cordillesa Blanca Baiholich (Pciford \& Alherion 1996). $s=$ Bega Batholith, Lachlan Fold Bell (Chappell el al. I9911. 6=Ceniral Spaio Herogniar Belı (Villoseca et al. 1998). 70 Higher Hinialaya (Le Forl el al. 1987). 8- Averaged upper contineolal crust (Wedepohl 1991). Tooalites ure the most abundant rock lype in coastal batholiths (Pilcber et al, 1985: Barkcr \& And 1990) bul granodiorics dominate in inbonrd bniboliths of accicc contiocniol nuorgins (Boteman al al. 1963; Solocby at al. 1990). Cordiltera Blanca Bubolith lics inboasd of the Penuvian Coasial Babolitb, divecily over che massively thiekened Andean contincrial crusi (Pelfond \& Albetion 1996), in eransition 10 intracontinental line seporaies fetsic ( $265 \%$ in volume of felsic minerals) from more mafie rocks.

Calcdonian l-types, more lypical of introcontiaental zoncs, which usually plot in the IP held of Figure?

\subsection{Protolith type and the origin of peraluminous series}

It has become progressively uppareat that the main mechanism for generating imporzant volumes of acid peralumisous granitoids is via melcing of crusesl rocks. including basic mantle-derived protoliths (i.e. Miller 1985; Petford \& A thertoo 1996). In continental crustal settings, the three main protoliths whicb cas produce important volumes of acid peraluminous magmas include melosedimeris (metapelites), quarizreldspathic melaignoous rocks (grcywackes and orlhogneisses) and bosic melaigneous (amphibolites). On Figure 3 different compositional helds for these protoliths and the compositional paths of several melting experiments have been represenced. When melling occurs at low melt rractions, it is possiblc for the composition of the melts 10 plot in the $\int P$ field irrespective of the nature of the souree protolith. Even melaluminous melaigncous rocks such as reportcd by Concad et al. (1988) and Bcard el $\Delta l .(1993)$ and amphibolizes as reportco by Ellis \& Thompson (1986). Bcard \& Lorgren (1991). Palino Douce \& Beard (1995) and Springer \& Seck (1997), arc able 10 produce peraluminous felsic melts at low melting fractions and in mater-deficient condirions. In general, all the melts produced at low meling fractions are indistinguishable, alchough it is possible 10 observe a lendeney of pelilederived mcles 10 plot on the upper port of the $f P$ fiold (Fig 3). A nateclic granitic series sensu strics have few opporunitios to bccome more differenciaced by crystal fractionation and usually do not define clear pachs in the $\int P$ field. On the other hand, as stated earlier. $P$ granites could be highly fractionated magmas of the $m P$ or IP serics instead of primary anatectic leucogranites. So, the assumption that iwo mica leucogranites form a differenı magmatic suitc should be carcfully studied in each paricular case, as ihe in $P$ and IP peraluminous granitoid rypes could grade iolo highly felsic peraluminous leucogranites (Barborin 1996).

As the meling fraction increases, primary components of ithe prololith become progressively incorporated into the mell and thus, in the peraluminous granitic series. the more mafoc rocks of the suile beller image their source (Chappell \& White 1992).

When pelitic protoliths arc melicd. the compositionol paths of the resultant series mainly correspond 10 restite unmixing lines aod plot inside the hP ficld (sce Cooms, Layos or Kinsonan series). Io face, when a large amoont of restice is retained in the crystal-liquid musb. the resultant composiction could be similar 10 (hat of the pelicic souroc (Fig. 1). Neveriheless, some hP types do nol necersarily involve melting of a pelicic procolith. Experimencal data frow Holiz \& Johannes (1991) demonstrated that particulur melaigneous protoliths (i.e. peraluminous orthogneisses) could also generatc scries which plot in the lower part of the /IP ficld. In fact, tbe Tourem granites in nonhern Porlugal have been interpreted in this way (Holtz \& Barbey 1991). The possibility of generaling in $P$ iypes from felsic metaigneous sources bas been used as an argument against the equivalence of sirongly peroluminous granite and S-type (merasedimentary derived) granice (Miller 1985; Clemens \& Wall 1981). Melasedimentary 


\section{Acknowledgements}

Revisiod and comments made by Bemard Bonin. Wallace Piicher and Ed Siephens on a previous version have greally increased lbe quality of this work. This paper has also beocficd greally from delailed comments by Pcler E. Browin and an anonymous reviewer. This researcb was financiglly supported by the P\$96-0661 Projecl of the Ministerio de Educacion y Culure of Spain.

\section{References}

Barbarin. B. 1996. Genesis of the two main types of Deraluminaus granitolds Geologu 24, 295-8.

Earbero. L \& Villaseca. C. 1992 The Layos granile. Hereynian Comptex of Toledo Spain: an cxample of paraviochchonous rescite-rich granitc in a granulice area Traneactions of the Rojal Saciely of Edmbergh: Eorth Sciences 83, 12?-38.

Barke?. F. \& Arth, J. G. 1990 . Two Iraverses across the Cossi baiholich, soucheasiem Alaska. In Aadersoa. J. L. (cd.) The noivere and arigin of Cordiller on magnuurisus. Geological Saciely of Americo Asemois 174, 395-405.

Bateman, P. C. Clorke. L. D. Huber, N. X., Moore J. G. \& Rinelian, C. D. 1963. The Sierra Nevada barholith: A synihesis of reeent work across the cenisal parl. U.S. Geolngical Survey Profersional Paper 414D.

Beard, J. S \& Lolgren. G. E. 1991. Dehydrasion melting and watersoluratod mellius of baialic and andesilic ereensiones and amphibolites at 1, 3 and 6.9 kb. Sournol of Petrolog. 32, 365-401.

Beard, J. S. Abiiz R J. \& Lofgres. G. E. 1993. Experimerslal melling of ensial renolishs irom Kilbonume Hole. New Mexico and implicalions for the contaminauion and genesis of magnas Coneributions 10 Miseralugy and Petrology 115. 88-102

Chappcil, B. W. \& White A. J. R. 1974. Two contrasting granile iypes Pacific Geology \& 173 -4.

Chappell. B. WV. \& Whice. A. S. R. 1992. I- and S-lype granites in the Lachian Fold Bclt. Transaclions of the Ros: ol Sociely of Edinburght. Eurtis Seiencis B). $1-26$.

Chappell, 8. W., Whic, A. J. R. \& Williams, I. S. 1991. A Iransiers section ilirough graniles of the Lochlan Fald Belt. Second fiullous Sympasium Excursion Guide. Record 1991/22 BM R. Canberra.

Clark, R. C. \& Lyons. J. B. 1986. Pelrogencsis of the Kinsman intrusive suice: peraluminous granicoids of wesiers New Hampihire. Journal of Peirology 27, 1365-93.

Cemens. J. D. \& IValh V. J. 1981. Crysializalion and origin of some peraluminaus S-lype gronue magmas. Conadion Minerulogisi 19. $111-32$.

Conrall. W. K.. Nicholls I. A. \& Wall. V. J. 1988. Water-soluratod and undersaturaled melling of meialuminous aod peraluminous crustal compositions at $10 \mathrm{~kb}$ : evidence for the oripin of silieic magomas in the Taupo volesnic zonc. New Zesland. and olher oceurrencer Jourmal of Peirology 29. 76 $\$-803$.

Detoon, F. \& Le Fori. P. 1983 A chervical-mimcralogical elassification of common plutonic rocks and associalions. Transacilons of ilic Royal Soclecy of Edinburgh: Earlh Sciencex 73, 135-49.

Ellic. D. J. \& Thompson. A B. 1986. Subsolidus and partial meluing reaclions ill lie yuurL-excaso $\mathrm{CaO}+\mathrm{M}_{8} \mathrm{O}+\mathrm{Al}_{2} \mathrm{O}_{3}+\mathrm{SiO}_{2}+\mathrm{H}_{2} \mathrm{O}$ sysieni under walcrexcess and walerdefiacene conditions 10 $10 \times 6$ soroc implicalions for the origin of peraluminous melis lrom mafic rocks. Journol of Peirologj' 27, 91-121.

Gardion, V.. Thompson A. B. Grujic. D. \& Ulmce, P. 1995. Experimenesl meling bsotire + plagiocinse + quarex muscovite asseniblages and implicalions lor crusial melting jourmal of Geopliysical Research 100, B\&. 1558)-91.

Hinc, R.. Williams, I. S.. Chappell, B. W. \& While. A. J. R. 1978. Coniresis belwcen I- and S-lype granitoids of the Xosciusko Batholith. Journal of the Geological Socicis' of Austrafio 2S. 21 9-.34.

Holiz F. 1989. Imporance of mell Iraction Ind source roek composition in crustal genesis - the example of 1 wo granitic suites of nonhem Poriugal. Lirhos 24, 21-35.

Holl2 F. \& Barbey, P. 1991. Genesis of peraluminous granicti II. Mincralogy and chemistry of the Tourem Complex. Nortb Ponugal. Sequential melting vs retice unmixing Joursal of Peirolegy 32, 959-78.

Holo, F. \& Johanmes W. 1991 . Genesis of peraluminous granites 1. Experimereal iuverigation of illed compersitions al 3 und $5 \mathrm{~kb}$ and various $\mathrm{H}_{2} \mathrm{O}$ aclivitios Journol of Pelrolog) $32,915-38$.

Lameyre, J. 1988 Granile sellings and teconics. Rendicunci delln

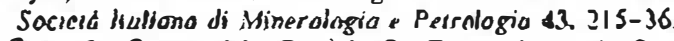

le Fon. P., Cuney. M. Deniel C Franoe-Lanord. C.. Sheppard,
S. M. F., Upreii, 8. N. \& Vida, P. 1987. Crusial generation of the Himalayan leucogranice recionopliysics 134 39-57.

Leger, J. M., Wang, X. \& Lomoyte. 1. 1990. Les levicogranites de Sajni-Gouscaud en Limousin. pérographie, èements majeurs el iraces dans ic sondage de Villectiabrollc (projecl Energeroc). Bullerin de la Sociéré Geologigue de la France VI, SIS-24.

Licw. T. C.. Finger. F. \& Höck, V. 1989. Tho Moldanubian graniloid pluloos of Ausiria: chemical add isolopic sludics bearing on their envirommenlad selling. Chemical Geology 76, 11-55.

Maniar. P. D. \& Piccoli. P. M. 1989. Teclonic discrimination of graniroids. Geological Sociely of Amerien Bullerin 101, 635-43.

McCanhy. T. C. \& Patiño Douce. A. E. 1997. Experimental evidence for high temperature felsic melis fortred during basaltic intrusion of the deep crust. Geology 25, 463-6.

Miller. C. F. 1985. Ace strongly peraluminous magmas derived from pelitic sedimeotary sources? Jownal of Grology 93, 673-89.

Nachil H. Razyfinahcfa, N.. Stussi, J. M. \& Carron J. P. 1985. Composition chimique des biolices el lypologie magmalique des granitioio. Coniples Rendus a liacadernic des Sciences de Paris $301,813-17$.

Patino Douce. A E \& Beard, J. S. 1995. Dohudracion-melcing of bionile gneiss and quarz amphionlice trom 3 co $15 \mathrm{kbar}$. Joumol of Peirology 36, 707-38.

Pariño Douce, A. E. \& Beard. J. S. 1996 effecl of P. /O, and $\mathrm{Mg} / \mathrm{Fe}$ ralio on dehydration melting of model melagrenuackes Joumal of Pelrology 37, 999-1024.

Pacino Duvce, A. E. \& Johnston. D. A. 1991. Phase equilibria and mell produclivily in the pelitic system: implications for the origin of peraluminous graniloids and aluminous granulites. Contriburions to Mineralogy and Peirolog), 107, 202-18.

Perford, N. \& Atherion. M. 1996. Na-rich panid melis from newly underplated basaltic crust: the Cordillera Blanea Batliolith, Perú. Journal of Petrology 37. 149I-521.

Pichavant, M., Kontak, D. J., Qriquev. L. Valencia-Herrera, J. \& Clark, A. H. 1988. The Miocenc Plioanc Macusani volcanics. SE Pcru il. Geochemisiry and origin of a felsic peraluminous magnia Cuntriburions 10 Mincralogy and Pelrolagy 100, 325-38.

Pitcher. W. S. 1983. Granice lype and cocionic environment. in Hsl. $X .1$. (ed.) Mountain Bullling Procceses, 19-40. London; Academic Preas.

Pitcher. W. S. 1993. The Nature and Origin of Graniles 1se edn. London: Chapman and Hal).

Pitcher, W. S. Atherion. M. P., Cobbing. E J. \& Beckinsale. R. D 1985. Magnianisnt ut $n$ Plute Edge: The Perubian Andes Glosgon: Bjackic,

Rogers. J. J. W. \& Greenbers, J. K. 1990. Lalc-ocoginic, posl ১rogenic. and anorogenie granites: distioclion by najor-clement and isace clement chemisiny and possible origins. Journal of Geology 98, 291-309.

Saleeby. J. B., Kistler, R. W., Longiaru S., Moorc. J. G. \& NotJeber\&. W. J. 1990. Middle Crubceous silicic metavolcanic rocks in the Kings Canyon ares. ceolral Sicrra Nevady, Californiz in Anderson. J. L. (ed.). The nature and origin of Cordilleran magmonism. Gealogical Sociel)' of America Memoir 17d, 251-70.

Shand. S. J. 1927. The esuprive rocks. Ncw York: Van Nosirand

Shimura T, Komsisu. M \& liyama. J. T. 1992. Gencsis of the lower crusial gamiel-orthopyroxene conalities (S-lyps) of the Hidaka Metamorptuc Bclt. northcm Japan. Trausactlous of the Royal Sociely of Enimburglt. Eorih Sciences 83. 259-68.

Springer. W. \& Seck. H. A 1997 . Portial fusion of basic granulites at 5 to $15 \mathrm{kbar}$ : implications for the origin oi TTG magmas. Comeribuilons 10 Mineralogy aild Pelralogy I27. 3045.

Slussi. J. M. Cuney. M. 1993. Modkla d'ivoluiton géochimic de granitoides peralumineux. L'exemple du complexe plutonique varisque du Millevaches Mussif central froncais. Bullelin de la Sociélé Géulogigive de la Fronce 164. S85-96.

Thompson, A. B. \& Connolly. J. A. D. 1995. Melting of the continental crust: Some thennal and petrologicsl consirainis on anatexis in continental collision zones and other loctonic settings. Journal of Geophysical Reseorch 1100, 88, 15565-79.

Vielzeuf D. \& Holloway. J. R. 1988. Experimental determination of the fluid-absent melling relacions in the pelitic system. Consequeoces for crustal differentiation. Comiributions in Mincralogy and Pedrology 92 257-76.

Villaseca C. \& Barbero. L 1994. Chemical variability of Al-Ti-Fe-Mg roinerals in peraluminous graniloid rocks from Central Spain. European Jourial of Mfirserulugy G, 69?-710.

Villaseca C. Barbero. L. \& Rogers. G. 1998. Cruseal origin of Hercynian peraluminous granisic baiholiths of Ceritral Spain: petrological, geochemical and isolopic (Sr. No) conseraints. Liethos 43, 55-79. 
Wodepobl, K. H. 1991. Chemical composition and fraclionation of the contineneal crust. Geologische Rundschou 80. 207-23.

Whalen, J. B. 1985. Geochemisiry of an island-are plutoric suive ibe Uasizau-Yau Yau intrusive complex. New Brilain P.N.G. Joumal of Parology 26, 603-32.

Whice. A. J. R. Q Chappelh \& W. 1988. Some supracruslal (S.lype) granites of the Lachlan Fold Beli. Tronsuctions of the Royal Socidty of Edinburgh: Eurth Sciences 79, 169-81.

Whice A. J. R, Willisms, 1. S. \& Chappel, 8. W. 1977. Geology of the Berr.dole 1:100000 Sheer (8625). Syduey: Geological Survey NSW.
Wickham. S. M. 1987. Cruslal arstexik and granike petrogeoesis during low.pressure regional melamorpbism: The Trois Siceneurs Massir. Pyreneas, France. Journal of Peirology 28, 127-69.

Willsamson 8. J. Dowacs. H.. ThinwaU. M. F. \& Besind A. 1997. Geocbronial Donstraidis on resilte composilion and unmixing in the Velay ensioctic granite. Frencb Massil Ceniral. Lichos 40. 295-319.

Wolf, M. B. Wyllic, P. J. 1994. Debydsalioo mclitiog of amphibolise at $10 \mathrm{kbar}$. the efiects of iemperalure and lime Coneributions 10 Mineralogy und Peirology 115, 369-83. 